\title{
INTELLECTUAL PROPERTY MANAGEMENT IN STARTUPS - PROBLEMATIC ISSUES
}

\author{
AgNiESZKa BARAN, Asel Zhumabaeva
}

\begin{abstract}
A B S T R A C T
This paper describes the most important problems related to the management of intellectual property in startups. Startups have become an inseparable element of the innovative economy. Many of these companies base their development on intellectual capital and innovations. In this context, it is extremely important to legally secure the innovations and protect intellectual property. These activities can often be the decisive factor in the development of startups. This article aims to identify, analyse and evaluate the most important issues related to the management of intellectual property in startups. The first part of this paper presents the performed literature review, which mainly concerns the definition of innovation, the state of entrepreneurship in Poland, and the definition of a startup. The second part of the article deals with the main problems related to the management of intellectual property in startups. It is divided into three issues: underestimating the importance of intellectual property, the lack of intellectual property management strategies in startups and financial challenges of startups. The main results of the research indicate that many startups still have low awareness of what is intellectual property and what can be the consequence of using exclusive rights of others. The protection of intellectual property should become one of the elements of business strategies. However, startups find that the creation of the strategy and its implementation is rather expensive.
\end{abstract}

KEY WORDS

startup, intellectual property, strategy, management, entrepreneurship

DOI: 10.2478/emj-2018-0012
Corresponding author:

Agnieszka Baran

Bialystok University of Technology, Faculty of Engineering Management, Poland e-mail: a.baran@pb.edu.p

Asel Zhumabaeva

Graduate of Ala-Too International University, Faculty of Economic and Administrative Sciences, Kyrgyzstan

e-mail: asel.zhumabaeva136@ gmail.com

\section{INTRODUCTION}

Innovation is considered to be a key growth factor of competition and economic growth (Kononiuk \& Nazarko 2014). Innovation is currently one of the most important factors of socio-economic development of countries and regions. All countries are designing development strategies based on innovations. Innovations are seen as a chance for rapid development and increased competitiveness in the international arena. The innovation of a given economy is measured through the number of submitted patents, the number of registered patents and the number of quoted patents. The number of patents shows the level of awareness regarding the need for protecting intellectual property, while the number of granted patents reflects the quality of solutions. Car- 
ing for intellectual property has a positive influence on the economy and patents, and other forms of intellectual property are a source of economic benefits. Many countries in the world saw increases in filing activity for patents, trademarks and industrial designs. Globally, a total of 3.1 million patent applications were filed with patent offices worldwide during 2016. About 1.3 million patent applications were filed with China's State Intellectual Property Office (SIPO). Other notable trends include large increases in trademark filing activity in Japan, the Russian Federation and India, and rapid growth in industrial design filing activity in the Russian Federation and at the European Union Intellectual Property Office (World Intellectual Property Organization, 2017). Patent applications filed by Polish inventors, companies and research institutions with the European Patent Office (EPO) grew by $14.1 \%$ in 2017 , one of highest growth rates and well above the EU 28 (EPO, 2017).

Intangible properties are becoming increasingly important for innovative companies, especially small and medium-sized companies. The ability of companies to incorporate innovations is one of the most significant signs of their modernity, effectivity and productivity. Innovations are currently considered as the basic indicator of the development of a company, leading to the enrichment of the market in new products and services of high quality and organisational transformations within the company and its surroundings (Madyda \& Dudzik-Lewicka, 2014). Strong competition forces companies to seek for new methods of production, the introduction of new products and improvement of existing ones. However, it is highly significant that the companies are aware of the intellectual capital, human resources and intangible properties in their possession, all of which can be of substantial value. The awareness of their existence and their correct identification can become one of the pillars of the success of the enterprise. On the other hand, the lack of protection of intellectual property rights or the improper securing of the purchase of such rights can put a developing enterprise in a difficult situation and even lead to legal disputes.

At present, startups have become an inseparable element of the innovative economy. Many of these companies base their competitive edge on intellectual capital and innovations. In this context, it is extremely important to legally secure the intangible goods belonging to a given company, as well as to constantly increase the knowledge on management and protection of intellectual property, especially in the area of effective transfer of technologies. These processes can often be the decisive factor in the development of startups.

The article aims to identify, analyse and evaluate the most important issues related to the management of intellectual property (IP) in startups. As part of the research, the authors reviewed the literature and current reports on the state of startups.

\section{LITERATURE REVIEW}

Innovations are one of the most characteristic features of the contemporary economy. Innovation is the process of transforming new ideas, new knowledge into new products and services. The literature contains many definitions of innovation. Schumpeter classifies innovation into five categories as follow:

- the launch of a new product or species of the already known product,

- application of new methods of production or sales of a product (not yet proven in the industry),

- opening of a new market (the market, for which a branch of the industry was not yet represented),

- acquiring new sources of supply of raw material or semi-finished goods,

- new industry structure such as the creation or destruction of a monopoly position (Śledzik, 2013).

Innovation is understood in a wide spectrum and is a common symbol for change, something new, expressing itself as new products, innovative technologies, non-traditional services or unconventional management methods (Sikora \& Uziębło, 2013). It is also considered as the final stage of the creation of new material reality, the first use of new ideas in practice (Bogdanienko, Haffer \& Popławski, 2004). Many theoreticians of management see innovations as a process occurring in the industry, more precisely as the first market introduction (implementation) of a new product, process, system or device, the first usage of an invention (Jasiński, 1997). Some authors treat innovations in a broader sense, stating that it is a sort of creative changes, occurring not only in industry but also in other systems: social, economic, technological, environmental etc. (Marciniak, 2008). Innovation is an act of introducing something new, a new idea, more effective device or process. Some authors claim that the terms "innovation" and "invention" are equated, being defined as a complex developing process of innovation creation, distribution, 
use, focused on efficiency growth and development of innovative activities (Manuylenko et al., 2015). In the public opinion, innovations are often equated with inventions. However, some authors present a different approach, these are two different concepts. "Invention" can be defined as the creation of a product or introduction of a process for the first time. "Innovation," occurs if someone improves on or makes a significant contribution to an existing product, process or service. The creator of the Schumpeter innovation theory clearly pointed to the existence of differences between the invention and innovation. He emphasised that only a few entrepreneurs were able to see the potential of a given invention and use it for their benefit (Landreth \& Colander, 2005).

In the modern economy, innovations are closely connected to entrepreneurship. Innovations are currently the most efficient way for small and mediumsized companies to exist and remain in the market. A company is considered innovative if it creates, absorbs and obtains new products or services as well as those which are characterised by the ability to constantly adapt to changes in their environment. An innovative company constantly generates and realises innovations, gains recognition among customers due to its high level of modernity and competitiveness and possesses the ability to adjust its management methods to a specific task (Sosnowska, Łobejko \& Kłopotek, 2000).

According to the Central Statistical Office, in recent years, entrepreneurship in Poland can be characterised by three significant trends. Firstly, over the course of the last few years, the number of companies has been growing dynamically. Every year, 1/3 of a million new companies are created, and this number has been at a similar level for a longer period. Secondly, the quality of the Polish entrepreneurship is improving. Polish companies, as a group, take an increasingly larger part in the building of social welfare. The data shows that they are responsible for an increasingly larger part of the Polish GDP. Tendencies also point towards the improvement of the company structure from the point of view of legal forms. The percentage of companies as legal entities is increasing while that of companies as natural persons is decreasing. Thirdly, there is a growing openness of entrepreneurs and their focus on the development. Polish companies invest increasingly more, and they design and implement innovations, although the scale of developmental activities is still not very large. At the same time, the number of persons working at an individual company is decreasing, which is partly connected to the numbers of new small companies. Unfortunately, one of the visible tendencies is also the decreasing percentage of innovators (Polish Agency for Enterprise Development, 2017). Despite this, expenditure on innovative activities is increasing, although this is a tendency visible mainly in industrial companies.

Since a few years, startups are being mentioned in the context of innovation as a new phenomenon which are being treated as a development motor for the economy. A startup is a new company, with no experience or knowledge, which begins to use the opportunities entering new areas. It can be stated that it is a specific period in the life of a company, a very difficult period, during which the company is fighting for its survival. Recent OECD work has shown that new and young firms contribute disproportionately to job creation. Startups may also be more effective in exploiting new technologies, which can help address some of the major policy challenges of our times (e.g., climate change, aging society). Innovative startups can also be instrumental in achieving more inclusive societies by promoting social mobility. However, countries and regions, differ significantly in the degree to which innovative businesses are created and prosper (Breschi et al., 2018).

Currently, creating startups is a global trend. Many cities and countries continue to seek better ways to create a strong environment for startups. Global Startup Ecosystem Report and Ranking 2017 is based on a year's worth of research, spanning a whopping 10000 startups and 300 partner companies. Startup Genome assessed 55 startup ecosystems across 28 countries. The report was made as result of speaking with entrepreneurs and massive amounts of data on startups. It examined how cities help to grow and sustain startup ecosystems through eight major factors: funding, market reach, global connectedness, technical talent, startup experience, resource attraction, corporate involvement, founder ambition and strategy. Among the top 20 startup ecosystems, nine are located in North America, six in Europe, with the remaining five in Asia. The role of Asian startups is increasing. Beijing and Shanghai appeared on the map of significant startup ecosystems. Unfortunately, Polish startups do not play a significant role in this global ranking so far (Startup Genome, 2017). However, Poland is becoming attractive due to the low cost of hiring software developers, good location and low office rents in large cities, compared to other European countries. 
There are many definitions of startups, such as using the term to refer to an enterprise in which the processing of information and derivative technologies are key elements of the business model. The definition of a startup will, however, be different for enterprises in the initial stages of development and those which already are mature enterprises. Often startups, after finding their business model, transform into other organisations, e.g. micro-enterprises or corporations. Others remain as startups for a longer period, operating in a non-stable and uncertain market environment (Skala, Kruczkowska \& Olczak, 2015; Magruk, 2017). A startup is not just a small company; it is an economic entity with slightly different needs. Startup ecosystems can be related to features of their national economies. It also affects the differences between startups in different parts of the world. Studies of start-up ecosystems need to consider their regional institutional and cultural context (Hemmert et al., 2016). There are various approaches to the issue of how long a functioning enterprise can be referred to as a startup. Some say that a startup is an enterprise created to create new products and services under the conditions of high insecurity, with a history no longer than ten years (Deloitte, 2016). The experiences of the most developed economies suggest that the development of such enterprises requires an efficiently functioning environment, referred to as an ecosystem. These young companies can face many challenges, such as legal regulations being a development barrier, or financial issues when the company cannot obtain financial support in the form of a loan in its initial phase of development. However, the understanding of the intellectual potential of a given company is also extremely important. In Poland, there is still low understanding of intellectual property, which can lead to the use of exclusive rights of others. Modern companies frequently have to pay attention to the necessity of protecting their intellectual property created by their employees and the knowledge they have accumulated. This necessity results from the fact that intangible assets including innovations and new technologies have become more significant, throughout the years, in the development of companies and creating a competitive edge. The protection of intellectual property should become one of the elements of the strategy of companies. However, it is not always so, and entrepreneurs including startups are not always aware of the importance of this issue.

\section{DISCUSSION OF THE RESULTS}

\subsection{THE IMPORTANCE OF INTELLECTUAL PROPERTY PROTECTION IN AN ENTERPRISE}

The matter of innovation is the main concern of any startup. Startups may face difficulties in developing certain product or service without the protection of innovation since competitors can easily steal one's idea if they know it is not well protected. Therefore, every startup should not underestimate the value of Intellectual Property Protection and be aware of how to deal with it. Intellectual property is important at every stage of business development. Many small businesses or young entrepreneurs do not understand various types of intellectual property and the protection that can be ensured for their products and services.

The basic condition which enables technological development is a modern, efficient and effective system for the protection of intangible assets. The ownership of rights to use inventions, technologies, designs or various trademarks is gaining more significance for the functioning of businesses. One of the most valuable assets of a modern business is a known and appreciated trademark, product name or packaging design. These elements create the market identity of a company and often determine the ability to generate profit. Also, the rights to use the created or purchased technology, construction solutions, created inventions or industrial designs have a significant influence on the value and market standing of a company and the perspectives for its further development. Another crucial issue is the company's confidentiality, which can be of strategic significance for its development. In the case of startups, the first important element of intangible resources is the idea for a new business itself, the knowledge regarding the chosen business profile, which can be a strategic resource.

In 2016, the Startup Poland foundation conducted surveys among Polish startups, which showed the condition of such companies. These entities were still young; their average age was under two years. This has put them in the third place in Europe with the youngest business, right after Romania (1.3 years) and Italy (1.7 years). There were very few foreigners working in Polish startups. 95 per cent of innovative companies were founded by Poles, and only five per cent of their employees were foreign nationals. Polish startups mainly developed software and services for 
mobile devices and focused on e-commerce. The level of patent activity in general among Polish enterprises was very low compared to European and world leaders. However, in startups created after 2015, the awareness of patent protection has been growing. Every fourth startup collaborated with a university, and a similar number worked with an individual researcher. Every tenth surveyed startup had its research laboratory. The survey shows that startups have insufficient knowledge regarding the means of protecting their inventions as well as the benefits of obtaining such protection. The low interest of Polish companies in applying for a patent is mainly due to barriers in cooperation between science and business. There are differences in the perception of the value of technology, problems with the transfer of rights and developing solutions in research and development units that are often divorced from the needs of the market (Skala \& Kruczkowska, 2016). Sometimes, start-uppers are concerned with the product or software development, taking care of the innovation. They do not think about registering the trademark, buying patent or acquiring trade secrets (Harroch, 2017). Patent applications are definitely not the end goal of a startup, they usually represent a stepping stone in the firm's development and can be seen as an indicator of success in acquisitions for firms that are not yet mature. It is recognised in the literature that startups that hold patents experience higher growth in terms of employment and sales (Farre-Mensa et al., 2015). Mann and Sager also claimed that for the great majority of startups the possibility of patenting is somewhat low on the list of investment criteria and the decision to patent is a routine rather than a strategic one. Startup firms for which patents are useful obtain patents in due course if the firm survives long enough for the patents to become valuable. Startups must account not only for the possibility that patents might impose substantial costs but also for the possibility that they provide substantial benefits (Mann \& Sager, 2007). Literature and reports indicate that the approach to intellectual property protection in startups is similar in most countries around the world. However, differences may result from different legal systems. The most specific situation is in the United States due to the dominant patent activity of large corporations. The literature on patent systems portrays small inventors, including startups, as suffering the most from the shortcomings of the patent system. This is connected with applying for patents, enforcing their patent rights, and defending themselves when sued by larger rivals. A chief criticism of the U.S. patent system is that it takes too long to approve or reject patent applications (Farre-Mensa et al., 2015). In some countries, the average time to grant from application now stands at ten years or more. For example, in Thailand, the average pharmaceutical patent granted in 2015 was 16 years old. In Brazil, patents in mobile technology fields are averaging more than 14 years old (Schultz \& Madigan, 2016). In Poland, the average time to grant from application stands at five years. Such a long waiting time is unhelpful for most inventors, businesses, and technology investors.

In the last decade, the approach of Asian countries to the protection of intellectual property has clearly changed. Before 1985, China had no patent law at all. The approach of Asian corporations to IP management has evolved in the past few years. Many companies are embracing global best practices in the field of intellectual property protection. Licensing and litigation are increasing across the region because companies are aware that having a high-quality IP portfolio is the key to staying competitive worldwide (Taylor, 2018).

Criticism of patent systems around the world has been rife in the last few years. The main problems are connected to lengthy waiting for a patent, high protection costs and complicated intellectual property regulations. Regardless of the disadvantages of this system, this is the best way to protect ideas and innovations.

\subsection{LACK OF THE INTELLECTUAL PROPERTY MANAGEMENT STRATEGY IN STARTUPS}

Effective management of intellectual property should be one of the basic elements of the company's development policy, which may significantly influence its increase in competitiveness in the market. Management of intellectual property in a company consists of the development of intellectual property, market analysis, protection of intellectual property rights, actions aimed at commercialisation, sharing the know-how and selling of the rights in possession (Truskolaski, 2014). The strategy of managing intellectual property should be a part of the general development strategy of a company. It should be individualised, related to the specific goals of the company, its size and business profile, which could influence the necessity to increase the focus on a specific type of protection of individual intangible assets. Complex innovation settings require firms' IP strategies to include protection and/or sharing of 
their own technologies on the one hand and access to others' technologies on the other hand (Holgersson et al., 2018). The fact is that the complex nature of intellectual property rights can have an impact on the creation of a startup strategy. However, some legal forms of protection of intangible goods are not known at all. The knowledge about the protection of intellectual property in enterprises is rather low.

In Poland, 34\% of entrepreneurs do not have an innovative strategy and do not foresee its implementation in the near future. $33 \%$ of companies declare that this strategy will be developed in the future. Only $18 \%$ of enterprises have such a strategy. A common reason for the implementation of the innovation strategy is the emergence of new technology or customer needs. Enterprises that have innovative strategies are usually business entities with a strong market position (Tarnawa, 2016).

Strategy for startups should chiefly include high economic and innovation risk, which is characteristic of such companies. The choice of the strategy is dictated by the specificity of the company, its business, institutional and market positioning. The company can choose an active strategy, passive strategy or entirely ignore the existence of intellectual assets and their economic significance. Larger companies can allow themselves to choose an active strategy because they possess greater financial resources and most possibly already play a significant role in the market. A young company will select a passive strategy, spending smaller amounts of money on the development and protection of intellectual resources. However, is this method of approaching the protection of intellectual resources appropriate for startups? A startup can choose an active strategy, as a subject, whose business activity is closely related to a specific innovation, it must decide regarding the method of protecting its innovation (Kasprzycki et al., 2008). Naturally, the cost of obtaining patents, especially in the European or international procedure means large expenses, but such a patent should protect the basic technology of a company and its competitive advantage, ensure income from licensing, or make the company more attractive for buyers or investors. Due to the financial limitations of startups they can also opt for choosing unpaid intellectual property protection, protecting their intangible assets through company confidentiality and copyrights. As startups often operate in the field of IT, it is often thought that since software is not subject to patents, the issue of property protection does not apply in this case. In Poland, the protection of software is managed through copy- rights and is protected in the same way as literary works. Such protection does not require registration or financial expenses, although the process of creating software to account for protection and coauthorship is relatively complex; therefore, specialist knowledge is required to be able to effectively use own exclusive rights. The trademark, which is visible on products, and the industrial design need to be kept in mind as important for every company. The protection of these intangible assets should also be taken into consideration. A startup company can decide to choose a two-tier strategy, i.e. choose more expensive but most efficient patent protection for a strategic product and maintain company confidentiality and protection of copyrights where possible. The OECD report shows that patent applications for startups are positively connected with the probability of obtaining funding for their development (Breschi et al., 2018).

There are still debates in the literature on whether the propensity rate to patenting increases with firm size. Some authors claim that firm size has a positive relationship with intellectual property management. Some studies report that small firms tend to file a patent more frequently than larger ones. In the U.S., large firms tend to use their own tools and decision criteria to determine how they strategically manage IP, while small businesses tend not to use a formal strategy (Cho, Kirkewoog \& Tugrul, 2018).

At the initial stage, startups require the support of a strategic partner, who can invest in the project, but also share their experience. In this context, it is important to remember undertaking actions to protect the knowledge or the idea which is in possession of the startup before it shares this idea with other subjects. The exchange of know-how should be protected by an appropriate confidentiality agreement. The use of such agreements and monitoring of intellectual property databases should be a key element for the economic development of startups. The identification of the activities of competitors, which is related to the creation of innovative technologies, should be a basic element of every company's operations. In the case of startups, this seems to be a necessity even at the stage of an idea for a business (Coalition for Polish Innovation, 2015).

The prevention of the infringement of exclusive rights owned by the company and third parties should be considered as a part of the intellectual property management strategy. Polish companies can easily obtain information on the granted and binding ownership rights of industrial property in the country, as the Polish Patent Office maintains a database of all 
industrial ownership rights granted by this office. Many patent databases and international reports are available as well. The monitoring of patent activities of competitors should also be included in the IP protection strategy of a company.

\subsection{Financial CHALlenges of STARTUPS}

For a long time, the basic problem with the development of innovations in Poland was the lack of a proper financing system of such enterprises. In the case of Polish companies, the problem lies in the lack of own as well as external financing sources, especially for new, innovative and risky enterprises, mostly in the research stage and in all fulfilment stages (Wiśniewska \& Janasz, 2015). The most popular financing source for Polish startups in the initial phase of development is own resources, the European Union grants and venture capital (VC) funds (Skala \& Kruczkowska, 2016). The source of external capital is venture capital (domestic or foreign), followed by public financing available from the European Union funding (via PARP (Polish Agency for Enterprise Development) or NCBiR (National Centre for Research and Development)). Slightly fewer startups use capital obtained from acceleration programmes (Beauchamp, Kowalczyk \& Skala, 2017). The main source of financing for startups in Europe is also the savings of the creators, financial resources obtained from friends or family and government grants or funds. Alternative financing sources are available, such as business angels or venture capital. Unfortunately, in Poland, the market for such financial support is very poorly developed (Cegielska \& Zawadzka, 2018). The high risk of an innovative enterprise and difficulties in the assessment of the potential of a given enterprise curb the enthusiasm of private investors. However, some positive changes can be seen, as in 2017, more startups have benefited from investments of a private business angel or a venture capital fund than from the European Union resources (Biskupski, 2017). VC firms can provide capital, strategic assistance, introductions to potential customers, partners, and employees. Comparing the innovation ecosystems of the EU and the US, there is a difference in the amount of venture capital available. In 2016, venture capitalists invested about EUR 6.5 billion in the EU compared to EUR 39.4 billion in the US. Europe's venture capital funds are not big enough to attract major institutional and private investors. Another problem is the source of the VC funding: compared to the US, the EU venture capital receives far more public funding and much less private investment (VentureEU, 2018). The difference between the US and European startups is that European entrepreneurs find it easier to raise initial capital, while US startups have better access to laterstage capital. There is no real single digital market in Europe. In the US or China, tech entrepreneurs gain immediate access to a massive market. In Europe, they still must navigate 28 different markets and regulatory regimes (Echiksone, 2017).

The protection of intellectual property is still rather expensive nowadays. The costs include mainly the designing and implementation of a management strategy regarding industrial property protection, the costs of legal services related with obtaining exclusive rights, administration fees, costs of legal disputes, in and out of court (e.g. arbitration). Of all the available forms of protection, patent protection is the most expensive. As protection solely by a national patent makes no sense, the obtaining of a European patent or a patent in a multinational procedure needs to be considered, this being a very expensive procedure, which can be very discouraging and problematic for startups.

In 2017, in Poland, the PFR Ventures (Polish Development Fund) platform launched, which is comprised of five venture capital investment funds. The aim of this platform is the development of innovative companies through financial and expert support. The development of startups will receive EUR 700 million by 2023 . The fund targets the development of small and medium-sized Polish innovative companies in their earliest (pre-seed) and initial (seed) stages of development. The result is expected to be a considerable improvement in access to financial means for innovative companies, attracting foreign capital, and buoying the domestic investment market (Beauchamp et al., 2017).

However, it seems that the issue of financing startups may not be the most important one as an increasing amount of money is becoming available for innovations in the market. A greater problem can be the support at the level of creating a business model, its adjustment to the business conditions within the country, as well as designing a development strategy, including the protection of intellectual property. 


\section{CONCLUSIONS}

Startups became a worldwide trend during the last decade all over the world. The number of people wanting to set up a business without or with minimum resources is rapidly increasing. The largest investments in IT and technology firms were mainly in the United States. Currently, the European market, as well as the Asian market is catching up fast.

Intellectual property represents an important financial and legal asset for companies, including startups. Intellectual property protects whatever value there is in the company (brands, inventions, design), and also contributes to its increase. Appropriate protection of intellectual property owned or used allows to gain competitive advantage, become recognisable, build reliability and reputation. For investors, startups with a solid intellectual property portfolio are attractive investment targets.

Management of intellectual property is a set of intertwined activities subordinate to major business goals of an enterprise. These activities cover identifying, acquiring, protecting, using and disposing of intellectual property assets and analysing applicability.

Startups face many challenges on their way to becoming a successful company. Even though the support for innovation has increased rapidly during the last decade and tends to grow even more by 2020, especially in the European Union, startups are still facing high fluctuations and competition in the market. The role of startups as contributors to economy is getting larger. However, these companies are still facing many problems. One of the most demanding and hardly implementable of them is the Intellectual Property Protection.

New enterprises have to decide on the intellectual property management strategies, and this strategy is recommended to be active. On the one hand, this way of protection can be costly and demanding. On the other hand, a patent should protect the company's basic technology and competitive advantage, provide licensing income or make the company attractive to buyers and investors. Due to the financial limitations of startups, they may opt for unpaid protection, protecting their intangible assets with business secrets and copyrights.

What seems to be the most difficult for startups are the financial issues, since there are always limited resources that a company possesses. As it was mentioned previously, new entities can choose the way of protection from among many available types. A patent is among the most expensive choices. Despite its high cost, it is also considered to be one of the safest solutions. Since protection only through the national patent does not make sense, one should consider obtaining a European Patent or an international procedure, which, however, is a very expensive procedure, very problematic for new entrepreneurs and may discourage startups from making this financial effort.

To sum up, the role of the Intellectual Property Protection in startups can be considered as one the most crucial in today's highly competitive business environment. To survive in such environment, newly based businesses have to manage intellectual property effectively.

\section{LITERATURE}

Beauchamp, M., Kowalczyk, A., \& Skala, A. (2017). Polish startups report 2017. Warszawa, Poland: Fundacja Startup Poland.

Biskupski, Z. (2017). Wizja Polski startupowej [Polish startup vision]. Kwartalnik Urzędu Patentowego, 33(3), 18-19.

Bogdanienko, J., Haffer, M., \& Popławski, W. (2004). Innowacyjność przedsiębiorstw [Innovation of enterprises]. Toruń, Poland: Uniwersytet Mikołaja Kopernika.

Breschi, S., Lassébie, J., \& Menon, C. (2018). A portrait of innovative start-ups across countries. Paris, France: OECD Publishing.

Cegielska, E., \& Zawadzka, D. (2018). Źródła finansowania startupów w Polsce [Sources of financing for startups in Poland]. Annales H - Oeconomia, 51(6), 53-61.

Cho, Y., Kirkewoog, S., \& Tugrul, D. (2018). Managing strategic intellectual property assets in the fuzzy front end of new product development process. R\&D Management, 48(3), 354-374.

Coalition for Polish Innovation. (2015). Start-up handbook. What start-ups should know about the law? Warszawa, Poland: Startup Poland.

Deloitte. (2016). Diagnoza ekosystemu startupów w Polsce [Diagnosis of the startups ecosystem in Poland]. Rzeszów, Poland: Deloitte Polska.

Echiksone, W. (2017). Step aside Silicon Valley, there is a new tech hub in town. World Economic Forum. Retrieved from https://www.weforum.org/agenda/2017/04/step -aside-silicon-valley-there-is-a-new-tech-hub-intown?utm_content=buffer755ff\&utm_medium = social\&utm_source=twitter.com\&utm_campaign= buffer

European Commission. (2018). VentureEU: Pan-European Venture Capital Funds-of-Funds Programme. Brussels, Belgium: European Commission.

European Patient Office. (2017). Welcome to the Annual Report 2017. European Patient Office. Retrieved from www.epo.org/annual-report2017 
Farre-Mensa, J., Hegde, D., \& Ljungqvist, A. (2015). What is a Patent Worth? Evidence from the U.S. Patent "Lottery". The Bright Side of Patents. USPTO Economic Working Paper, 2015(5), 1-48.

Harroch, R. (2017). Intellectual Property strategies for technology Startups. Forbes Magazine. Retrieved from https://www.forbes.com/sites/allbusiness/2017/06/ 06/10-intellectual-property-strategies-for-technology-startups/\#348d1fc9ab1b

Hemmert, M., Cheng, Y., Kohlbacher, F., Kotosaka, M., Loh, Ch., \& Waldenberger, F. (2016). High-tech startup ecosystems in East Asian agglomerations: Are they different from the West? Tokyo, Japan: German Institute for Japanese Studies.

Holgersson, M., Granstrand, O., \& Bogers, M. (2018). The evolution of intellectual property strategy in innovation ecosystems: Uncovering complementary and substitute appropriability regimes. Long Range Planning, 51(2), 303-319.

Jasiński, A. (1997). Innowacje i polityka innowacyjna [Innovation and innovation policy]. Białystok, Poland: University of Bialystok.

Kasprzycki, D., Matczewski, A., Okoń-Horodyńska, E., du Vall, M., \& Wisła, R. (2008). Zarządzanie własnościa intelektualna $w$ przedsiębiorstwie - zasady korzystania $z$ wyników pracy intelektualnej wytworzonej $w$ przedsiębiorstwie [Intellectual property management in an enterprise - rules of using the results of intellectual work created in an enterprise]. Kraków, Poland: Jagiellonian University.

Kononiuk, A., \& Nazarko, J., (2014). Scenariusze w antycypowaniu $i$ kształtowaniu przyszłości [Scenarios in anticipating and shaping the future]. Warszawa, Poland: Wolters Kluwer.

Landreth, H., \& Colander, D. C. (2005). History of economic thought. Warszawa, Poland: PWN.

Madyda, A., \& Dudzik-Lewicka, I. (2014). Innowacyjność a rozwój małych i średnich przedsiębiorstw [Innovation and the development of small and medium enterprises]. ZS WSH Management, 2014(1), 133-140.

Magruk, A. (2017). Concept of uncertainty in relation to the foresight research. Engineering Management in Production and Service, 9(1), 46-55. doi: 10.1515/emj2017-0005

Manuylenko, V., Mishchenko, A., Bigday, O., Putrenok, Y., \& Savtsova, A. (2015). A Comprehensive Definition of the Concept of Innovation in Russian and International Science. International Journal of Economics and Financial Issues, 5(4), 1029-1037.

Mann, R., \& Sager, T. (2007). Patents, venture capital, and software start-ups. Research Policy, 36, 193-208.

Marciniak, S. (2008). Innowacje i rozwój gospodarczy [Innovation and economic development]. Warszawa, Poland: PWE.

Polska Agencja Rozwoju Przedsiębiorczości [Polish Agency for Enterprise Development]. (2017). Report on the state of the sector of small and medium enterprises in Poland. Warszawa, Poland: Polska Agencja Rozwoju Przedsiębiorczości.
Schultz, M., \& Madigan, K. (2016). The Long Wait for Innovation: The Global Patent Pendency Problem. Arlington, USA: Center for the Protection of Intellectual Property.

Sikora, J., \& Uziębło, A. (2013). Innowacja w przedsiębiorstwie - próba zdefiniowania [Innovation in the enterprise an attempt to define]. Management and Finance, 2(2), 351-376.

Skala, A., Kruczkowska, E., \& Olczak, M. A. (2015). Polskie startupy [Polish startups]. Warszawa, Poland: Startup Poland.

Sosnowska, A., Łobejko, S., \& Kłopotek, A. (2000). Zarządzanie innowacyjna firma [Management of an innovative company]. Warszawa, Poland: Difin.

Startup Genome. (2017). Global Startup Ecosystem Report. Startup Genome. Retrieved from https://startupgenome.com/all-reports/

Śledzik, K. (2013). Schumpeter's view on innovation and entrepreneurship. In S. Hittmar (Ed.), Management Trends in Theory and Practice (pp. 89-95). Zilina, Slovakia: University of Zilina.

Tarnawa, A. (2016). Kompetencje i strategie innowacyjne polskich firm - wyniki badań PARP [Competencies and innovative strategies of Polish companies - results of PARP research] [PowerPoint slides]. Retrieved from https://badania.parp.gov.pl/images/Konferencja_ badawcza_2016/3at.pdf

Taylor, K. (2018). 3 IP Trends to Watch in Asia Pacific in 2018. ANAQUA. Retrieved from https:// www. anaqua. com/ resources/blog/3-ip-trends-watch-asiapacific- 2018

Truskolaski, S. (2014). Znaczenie transferu wiedzy w działalności innowacyjnej przedsiębiorstw [The importance of knowledge transfer in the innovative activity of enterprises]. Warszawa, Poland: Difin.

Wiśniewska, J., \& Janasz, K. (2015). Innowacje $i$ procesy transferu technologii $w$ strategicznym zarzadzaniu organizacjami [Innovations and processes of technology transfer in the strategic management of organizations]. Warszawa, Poland: Difin.

World Intellectual Property Organization. (2017). World Intellectual Property Indicators 2017. Geneva, Switzerland: WIPO. 